\title{
A MULTI-MODEL ASSESSMENT OF CLIMATE CHANGE IMPACT ON HYDROLOGICAL REGIME IN THE CZECH REPUBLIC
}

\author{
MARTIN HANEL ${ }^{1,2)}$, ADAM VIZINA ${ }^{1,2)}$, PETR MÁCA ${ }^{2)}$, JIŘÍ PAVLÁSEK ${ }^{2)}$ \\ ${ }^{1)}$ Department of Hydrology, T. G. Masaryk Water Research Institute, p. r. i., Podbabská 30, 16000 Prague, Czech Republic; \\ Mailto: martin_hanel@vuv.cz \\ ${ }^{2)}$ Faculty of Environmental Sciences, Czech University of Life Sciences Prague, Kamýcká 129, 16521 Prague, Czech Republic.
}

In present paper we assess the climate change impact on mean runoff between the periods 1961-1990 (control period) and 2070-2099 (scenario period) in the Czech Republic. Hydrological balance is modelled with a conceptual hydrological model BILAN at 250 catchments of different sizes and climatic conditions. Climate change scenarios are derived using simple delta approach, i.e. observed series of precipitation, temperature and relative air humidity are perturbed in order to give the same changes between the control and scenario period as in the ensemble of 15 transient regional climate model (RCM) simulations. The parameters of the hydrological model are for each catchment estimated using observed data. These parameters are subsequently used to derive discharge series under climate change conditions for each RCM simulation. Although the differences in the absolute values of the changes in runoff are considerable, robust patterns of changes can be identified. The majority of the scenarios project an increase in winter runoff in the northern part of the Czech Republic, especially at catchments with high elevation. The scenarios also agree on a decrease in spring and summer runoff in most of the catchments.

KEY WORDS: Climate Change, Multi-Model Assessment, Czech Republic, Runoff.

Martin Hanel, Adam Vizina, Petr Máca, Jiří Pavlásek: DOPADY KLIMATICKÉ ZMĚNY NA HYDROLOGICKÝ REŽIM V ČESKÉ REPUBLICE PODLE SOUBORU KLIMATICKÝCH MODELŮ. J. Hydrol. Hydromech., 60, 2012, 3; 21 lit., 5 obr., 2 tab.

V článku předkládáme výsledky modelování změn hydrologického režimu v důsledku změn klimatu mezi časovými obdobími 1961-1990 a 2070-2099 podle souboru patnácti regionálních klimatických modelů pro 250 povodí v České republice. Hydrologická bilance byla modelována pomocí konceptuálního hydrologického modelu BILAN. Časové řady ovlivněné změnou klimatu byly získány jednoduchou přírůstkovou metodou, tj. pozorované časové řady srážek, teplot a vlhkostí vzduchu (vstupy do modelu BILAN) byly opraveny pro každou simulaci pomocí přírůstkových faktorů tak, aby měsíční změny těchto veličin byly stejné jako podle uvažované simulace klimatického modelu. Hydrologický model je nakalibrován s využitím pozorovaných dat, identifikované parametry jsou následně využity pro simulaci hydrologické bilance pro řady ovlivněné klimatickou změnou. Základní podstata možných změn hydrologické bilance na území České republiky vyplývá z projekcí srážek a teplot pro Evropu, tj. postupné zvyšování teplot během celého roku a pokles letních, růst zimních a stagnace ročních srážek. V období od začátku podzimu do začátku léta dochází $\mathrm{k}$ růstu srážek, jenž je doprovázen řádově stejným růstem územního výparu způsobeným růstem teplot. $\mathrm{V}$ letním období dochází $\mathrm{k}$ poklesu srážek a $\mathrm{v}$ důsledku úbytku zásob vody v povodí nemůže docházet $\mathrm{k}$ výraznému zvyšování územního výparu. Důležitým faktorem ovlivňující změny odtoku je posun doby tání $\mathrm{v}$ důsledku vyšší teploty přibližně $\mathrm{z}$ dubna na leden-únor. Změny odtoku $\mathrm{v}$ období leden-květen jsou tedy dominantně určeny právě odlišnou dynamikou sněhové zásoby, změny v letním období zejména úbytkem srážek. Výsledné odhady změn odtoku jsou zatíženy značnou nejistotou, nicméně lze identifikovat robustní jevy společné pro řadu simulací. Jak ukazují výsledky, na většině modelovaných povodí je pokles odtoků v období od dubna do října společný valné většině modelů. Na druhé straně, růst odtoku v zimních měsících je značně nejistý. $\mathrm{S}$ tím souvisí i nejistota spojená se změnami roční bilance odtoků.

KLÍČOVÁ SLOVA: změna klimatu, hydrologický režim, Česká republika. 


\section{Introduction}

In the last decade a number of studies on climate change impact on water resources using the climate model simulations have been published (see e.g., Bates et al., 2008; Fowler et al., 2007; Graham et al., 2007b; Kilsby et al., 2007) also for the Czech Republic (Kašpárek et al., 2006; Hanel, 2007; Horáček et al., 2008; Vizina and Horáček, 2009; Hanel and Vizina, 2010). One of the simplest methods of transferring the climate model output into the hydrological model in the monthly time-step is the delta approach, i.e., the observed series are transformed in order to give the same changes between two periods as in the climate model. For instance, for temperature the average temperature difference for each month between present and future timeslices from climate model is added to observed monthly series. Similarly, for precipitation the observed precipitation is multiplied by the average ratio of mean monthly precipitation between present and future time-slices from the climate model. This method has been criticized for ignoring the changes in variability (e.g. Graham et al., 2007a), however, it still provides a basic insight into the changes of monthly runoff in the sense of traditional sensitivity analysis.

The changes in precipitation over the Czech Republic are somewhat ambiguous, since the Czech Republic belongs to the transition between an increase in precipitation projected by a number of climate models for Northern Europe and its decrease agreed by many climate models for Southern Europe (e.g. Christensen et al., 2007). It is therefore evident, that projections of a single climate model for this area can be misleading. Although this has been reflected in the assessment of possible changes in future precipitation (Kyselý et al., 2011; Hanel and Buishand, 2012), the studies considering the changes in hydrological balance in the Czech Republic have always been based on a small number of climate model simulations (see e.g. Hladný et al., 1997; Kašpárek, 1998; Němečková et al., 2011). Recently, a relatively large number of regional climate model simulations are available e.g. from the EU funded ENSEMBLES project (Hewitt and Griggs, 2004) and also multi-model studies on climate change impact on water regime became common (Graham et al., 2007a; Fowler and Wilby, 2010).

In present paper, we consider fifteen RCM simulations to derive climate change scenarios for 250 catchments of different areas and climatic conditions in the Czech Republic using simple delta approach for the scenario period 2070-2099. The water balance under observed and climate change conditions is subsequently modelled with a conceptual hydrological model BILAN and the relative and absolute changes in projected runoff and other relevant components of the water balance with respect to the control period (1961-1990) are discussed. However, rather than the (absolute or relative) value of these changes we further focus on their uncertainty with respect to the agreement between the climate models. Such an extensive study have not been conducted for the examined area. In addition, although the uncertainty in projected changes in runoff has been assessed for various catchments around the world, this information has only very rarely been used to identify regional differences in projections and their consequences.

Data, hydrological model and the derivation of the climate change scenarios are described in the Data \& Methods section. The results focusing on the uncertainty in the projected relative changes in runoff are presented in the Results section. The paper is closed with Conclusions.

\section{Data and methods}

The Czech Republic is a small country in the middle of the Europe. The spatial and temporal variability of precipitation in this area is relatively large. This is partly due to the complex orography and partly because it is a region in which Atlantic, Mediterranean, and continental influences meet (Kyselý and Beranová, 2009). The lowest mean annual precipitation totals are less than $450 \mathrm{~mm}$ and the highest are more than $1500 \mathrm{~mm}$. Hydrological regime in the Czech Republic is dominated by precipitation. Mean monthly runoff is typically largest in the end of winter or early spring due to snowmelt. Minima are experienced in the late summer or early autumn.

The hydrological model BILAN (Tallaksen and van Lanen, 2004) has been used for assessing the water balance components of a catchment in a monthly time step. The structure of the model is formed by a system of relationships describing basic principles of water balance on ground, in the zone of aeration, including the effect of vegetation cover, and in groundwater. Air temperature is used as an indicator of energy conditions, which affect significantly the water balance components. The 
input data of the model are monthly series of basin precipitation depth, air temperature and relative air humidity, which are obtained by interpolation of the station data to the area of the basin considering the distance from the centre of the basin and orography. For calibration of the eight model parameters, a monthly runoff series at the outlet from the basin is used.

The locations of the 250 catchments considered in this study are indicated in Fig. 1a). For all basins at least 15 years of data were available, the average record length was 31 years. The number of stations with observations (Fig. 1b) was largest for the period 1980-1990 (note, that the figure considers data that were available to the authors, more data exist in the database of the Czech Hydrometeorological Institute.) Since the available periods differ considerably among the catchments, the observed data have been used only for calibration of the hydrological model. For the modelling of the hydrological balance in the control period we further considered the gridded data (further CHMI_OBS) produced by the Czech Hydrometeorological Institute (precipitation, temperature and relative air humidity), which were derived by spatial interpolation of point measurements (Štěpánek et al., 2011) and are available for the whole Czech Republic for the period 1961-2007 (which is not the case for the station data). The gridded data have been used to simulate the water balance for the control period with the pa- rameters of the hydrological model previously calibrated using the observations.

In present paper we considered 15 RCM simulations (Tab. 1). Except CHMI_ARP, which was derived by the Czech Hydrometeorological Institute within a national project ("Refining of current estimates of impacts of climate change in sectors of water management, agriculture and forestry and proposals of adaptation measures"), the RCM simulations were conducted in the framework of the EU funded ENSEMBLES project. The RCM simulations were driven by six simulations of four climate models all forced by the SRES A1B emission scenario. All simulations use rotated longitude-latitude grid with horizontal resolution $\approx 25 \mathrm{~km} \times 25 \mathrm{~km}$ and span the period 1961-2099. For each RCM simulation $\approx 130$ grid boxes relevant for the Czech Republic have been considered.

The climate change scenarios have been derived by a simple delta approach, which is based on transformation of observed series by delta factors calculated for each month and RCM simulation. The changes in monthly mean between the transformed and observed series are then identical to the changes in the RCM simulations. The delta factors for precipitation $(P)$, temperature $(T)$ and relative air humidity $(H)$ corresponding to the changes between periods $a$ and $b$ were calculated for each month as

(b)

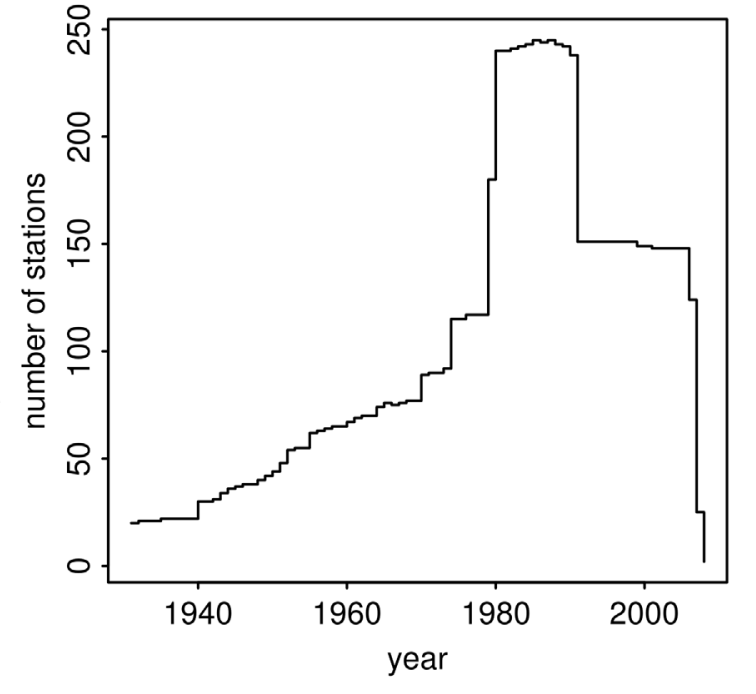

Fig. 1a) Study area and the centres of the simulated catchments (crosses). Black polygons indicate the river basin districts in the Czech Republic: HSL - Upper and middle Elbe, HVL - Upper Vltava, BER - Berounka, DVL - Lower Vltava, ODL - Odra and lower Elbe, ODR - Odra, Mor - Morava, DYJ - Dyje; b) Number of stations for which data are available for each year. 
$\mathrm{T} \mathrm{a} \mathrm{b} 1 \mathrm{e}$ 1. Summary of the RCM simulations.

\begin{tabular}{|c|c|c|c|}
\hline Acronym & $\mathrm{RCM}$ & Period available & Source \\
\hline ECHAM5 driven & & & ${ }^{1)}$ Royal Netherlands Meteorological Institute \\
\hline RACMO_EH5 ${ }^{1}$ & RACMO2.1 & $1950-2100$ & (KNMI) \\
\hline $\mathrm{REMO}$ EH5 $^{2}$ & REMO5.7 & $1951-2100$ & ${ }^{2)}$ Max Planck Institute for Meteorology (MPI), \\
\hline RCA_EH5 ${ }^{3}$ & RCA3.0 & $1951-2100$ & Germany \\
\hline RegCM_EH5 ${ }^{4}$ & RegCM3 & $1951-2100$ & ${ }^{3)}$ Swedish Meteorological and Hydrological \\
\hline HIR_EH̄ $5{ }^{5}$ & HIRHAM5 & $1951-2100$ & Institute (SMHI) \\
\hline \multicolumn{3}{|c|}{ HadCM3Q0, HadCM3Q3, HadCM3Q16 driven } & 4) Abdus Salam International Centre for Theoret- \\
\hline HadRM_Q0 ${ }^{6}$ & HadRM3.0 & $1951-2099$ & ical Physics (ICTP), Italy \\
\hline CLM_Q0 ${ }^{7}$ & CLM2.4.6 & $1951-2099$ & ${ }^{5)}$ Danish Meteorological Institute (DMI) \\
\hline HadRM_Q3 ${ }^{6}$ & HadRM3.0 & $1951-2099$ & ${ }^{6)}$ Met Office Hadley Centre, UK \\
\hline $\mathrm{RCA}_{\mathrm{Q}} \mathrm{B}^{3}$ & RCA3.0 & $1951-2099$ & ${ }^{7}$ Swiss Federal Institute of Technology Zurich \\
\hline HadRM_Q16 ${ }^{6}$ & HadRM3.0 & $1951-2099$ & $\begin{array}{l}\text { (ETHZ) } \\
{ }^{8} \text { Community Climate Change Consortium for }\end{array}$ \\
\hline RCA_Q16 ${ }^{8}$ & RCA3.0 & $1951-2099$ & $\begin{array}{l}\text { Community Climate Change Consortium for } \\
\text { Ireland (C4I) }\end{array}$ \\
\hline \multicolumn{3}{|l|}{ ARPEGE4.5 driven } & ${ }^{9)}$ National Centre of Meteorological Research \\
\hline HIR_ARP ${ }^{5}$ & HIRHAM5 & $1951-2100$ & (CNRM), France \\
\hline CNRM5_ARP $^{9}$ & CNRM-RM5.1 & $1951-2100$ & ${ }^{10)}$ Czech Hydrometeorological Institute (CHMI), \\
\hline CHMI_ARP ${ }^{10}$ & $\begin{array}{l}\text { ALADIN- } \\
\text { CLIMATE/CZ }\end{array}$ & $1961-2100$ & Czech Republic \\
\hline \multicolumn{4}{|l|}{ BCM2.0 driven } \\
\hline RCA_BCM ${ }^{3}$ & RCA3.0 & $1961-2100$ & \\
\hline
\end{tabular}

$$
\begin{aligned}
& \Delta_{m}^{P}(a, b)=\frac{\bar{P}_{m}^{b}}{\bar{P}_{m}^{a}} \\
& \Delta_{m}^{T}(a, b)=\bar{T}_{m}^{b}-\bar{T}_{m}^{a} \\
& \Delta_{m}^{H}(a, b)=\frac{100-\bar{H}_{m}^{b}}{100-\bar{H}_{m}^{a}}
\end{aligned}
$$

where $\bar{X}_{m}^{b}$ and $\bar{X}_{m}^{a}$ are the averages of variable $X$ from RCM simulation for month $m$ in the periods centred around $b$ (future) and $a$ (control), respectively. The form of Eq. (3) ensures that the relative air humidity does not exceed $100 \%$. For each RCM simulation, each grid box and each month we derived the delta factors between the control period 1961-1990 $(a=1975)$ and 30-year time slices centred around $b=1976, \ldots, 2085$ (i.e. for each grid box we obtained a series of delta factors). This allows the construction of the scenarios for any scenario period with reference year between 1975 and 2085. In present paper, however, we will focus on the changes between the control period (reference year 1975) and 2070-2099 (scenario period, reference year 2085) only.

The scenario series (indicated by asterisk) of precipitation, temperature and relative air humidity for year $i$ and month $m$ are then obtained using the observed data (indicated by superscript $o$ ) and corresponding delta factors as

$$
\begin{aligned}
& P_{i, m}^{*}=\Delta_{m}^{P}(a, b) P_{i, m}^{o} \\
& T_{i, m}^{*}=\Delta_{m}^{T}(a, b)+T_{i, m}^{o} \\
& H_{i, m}^{*}=100-\left[100-\Delta_{m}^{H}(a, b) H_{i, m}^{o}\right]
\end{aligned}
$$

with $a$ the centre of the observed series and $b$ the scenario reference year.

For each catchment the relative changes in runoff between the control and scenario periods were derived as follows:

a) Hydrological model BILAN was calibrated using observed data.

b) Gridded observations CHMI_OBS were used to simulate water balance for the control period (1961-1990) using the parameters calibrated in the previous step.

c) For each catchment, month and RCM simulation, the basin-average delta factors corresponding to the changes between the control and scenario period were obtained from the delta factors for the grid boxes intersecting the catchment area as an average weighted by the inverse distance between a grid box and the centre of the catchment. For small catchments at least four closest grid boxes were considered.

d) These basin-average delta factors were used for derivation of the scenario series of precipitation, temperature and relative air humidity for the scenario period. 
e) The series corresponding to the scenario period were used for modelling of the hydrological balance with the BILAN model.

f) The relative changes between the runoff series corresponding to the control and scenario periods were calculated for each month, catchment and RCM simulation.

\section{Results}

The changes in hydrological balance in the Czech Republic reflect the projected changes in temperature and precipitation, i.e. an increase in temperature during the whole year and a decrease in summer, increase in winter and no changes in annual precipitation. The absolute changes $[\mathrm{mm}]$ in important components of the water cycle (runoff, precipitation, actual evapotranspiration and snow melt) are summarized in Fig. 2a). The ensemble mean precipitation increases from the beginning of autumn until the beginning of summer. This increase is counterbalanced by an increase in actual evapotranspiration (estimated with the BILAN model) of approximately the same order (which is due to the increase in temperature). In the summer season precipitation decreases, however, the increase in actual evapotranspiration is not as large as would be expected from the increase in temperature (and hence potential evapotranspiration), since the increase in actual evapotranspiration is limited by the available water. An important factor for the changes in runoff is the shift in the snow melt from early spring to winter. From January to May the changes in runoff are dominated by the changes in the dynamics of snow, changes in the summer season are mainly related to the decrease in precipitation.

The changes in average timing of snow melt are demonstrated in Fig. 3. For the control period the snow melts (on average) mostly in March and partly in April for majority of catchments (> 200). This is not the case for the scenario period, when still (on average) snow melts mostly in March in the majority of the catchments, however, for more than 100 catchments the snow-melt peek shifts to January-February. The results indicate, that the shift in the timing of snow melt does not considerably depend on altitude.

The relative changes in runoff between the control and scenario periods are given in Fig. 2b) for each month. In the figure, the spatial variability of the ensemble-mean changes across catchments is indicated by the boxplots. In addition, the uncertainty arising from different RCM projections is represented by the dark (light) grey bars showing the ranges of relative changes spanned by $90 \%$ $(50 \%)$ of the RCM simulations in $90 \%(50 \%)$ of the catchments. The ensemble mean change (indicated by the boxplots) is less than 1 for the majority of the catchments (indicated by the area between the whiskers) from March to November. Largest mean decreases are projected for March-April $(\approx 22 \%)$ and August-November $(\approx 32 \%)$. The decrease in
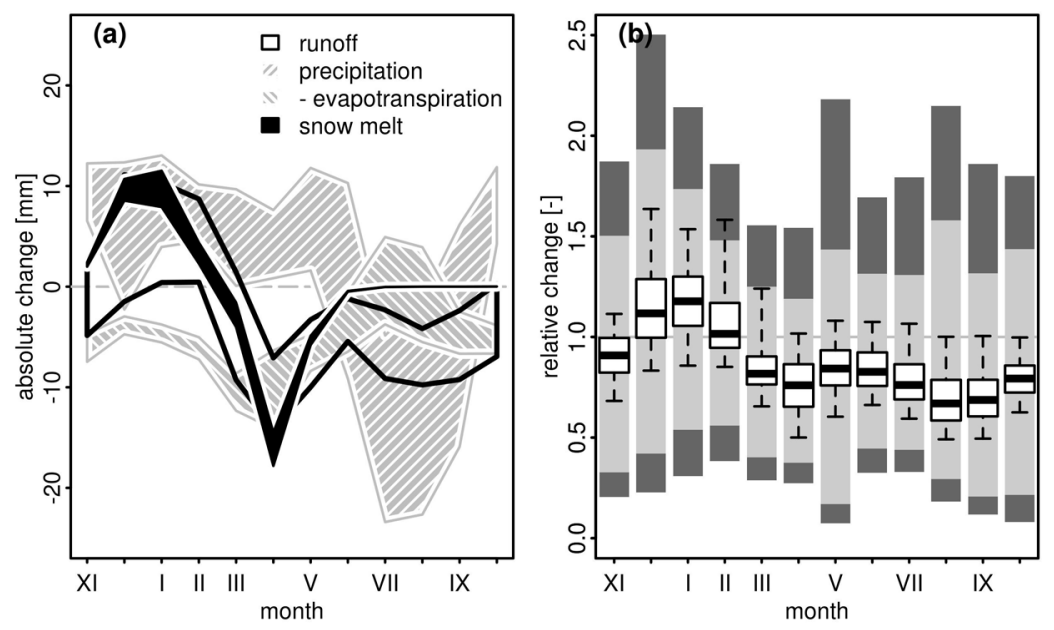

Fig. 2a) Absolute changes [mm] in runoff, precipitation, actual evapotranspiration and snow melt. The polygons represent the changes for all catchments; b) Relative changes in runoff between the scenario and control period. The boxplots represent the 5th, 25th, 50th, 75th and 95th percentile of the ensemble-mean changes in all catchments. The dark (light) grey bars indicate the ranges spanned by $90 \%$ (50\%) of the RCM simulations in $90 \%$ (50\%) of the catchments. 


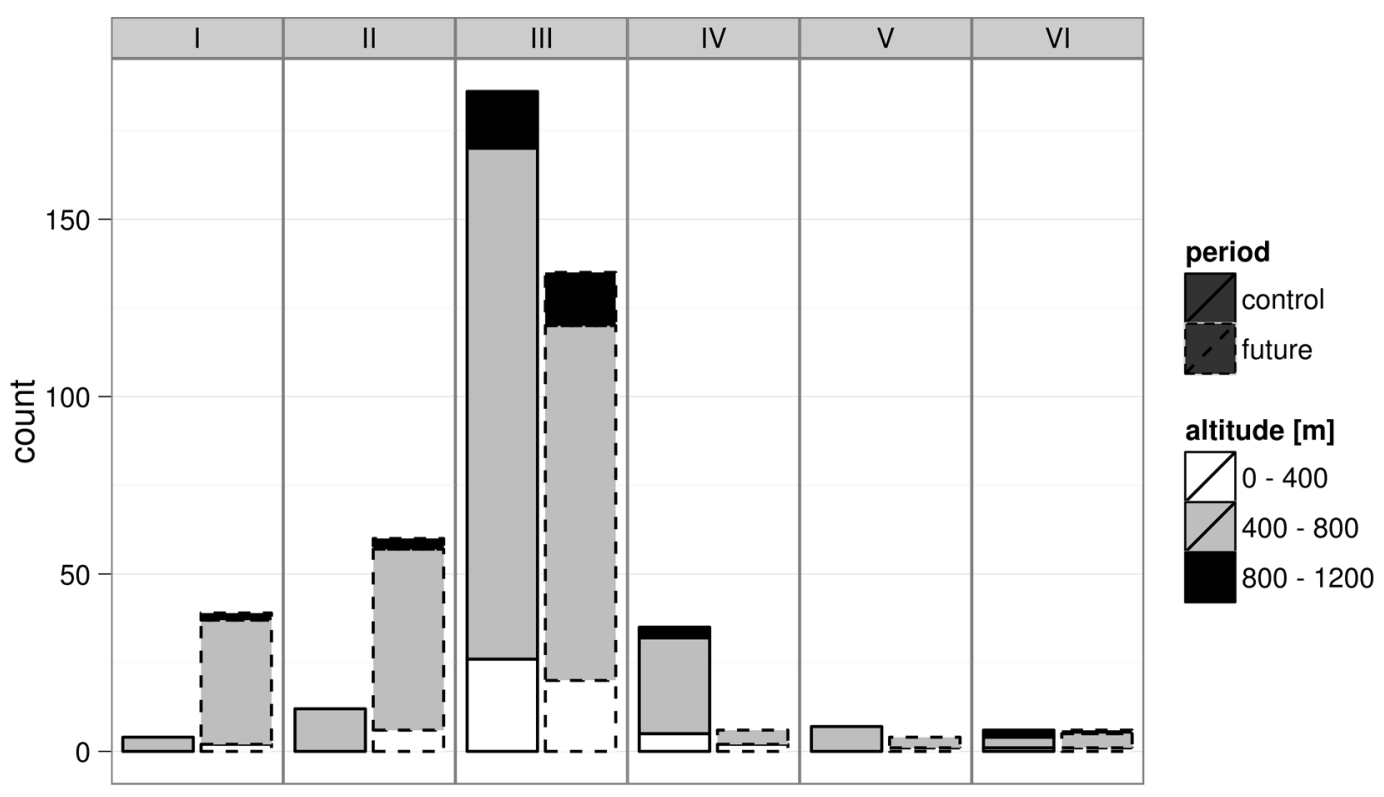

Fig. 3. Histogram of the average position of the snow-melt peak in all catchments for the control and scenario period.

March-April is mainly related to the shift in the snow-melt peak, as indicated in Fig. 2c). For the ensemble mean, the spread of the relative changes between the changes is usually around $50 \%$. However, the spread in the relative changes in runoff between the individual RCM simulations is much larger. This is indicated by the bars in the background of Fig. 2b) suggesting that using a small number of RCM simulations may be very misleading.

The absolute seasonal changes in precipitation, actual evapotranspiration and runoff between the control and scenario periods for the river basin districts in the Czech Republic (see Fig. 1) are given in Tab. 2. The differences in the changes between the river basin districts are usually up to $15 \mathrm{~mm}$ for precipitation and runoff and much less for actual evapotranspiration. Thus, the spatial distribution of the changes in runoff is dominated by the differences in precipitation, specifically the increase in autumn precipitation is a considerably smaller in Morava and Odra River basin districts.

Maps of relative changes between the control and scenario period for each season are given in Fig. 4. The increase in winter runoff (usually up to $20 \%$ ) is more pronounced in the north and northeast part of the Czech Republic. Runoff decreases in the other seasons, especially in the summer (20$-40 \%$ ) in the southern part of the Czech Republic. For the annual water balance the RCM simulations indicate a decrease (5-20\%), again especially in the south of the Czech Republic.
We further investigated the uncertainty related to the regional climate model. Fig. 5 shows maps of a number of RCM simulations giving the relative changes larger than $-20 \%$ (Fig. 5a), 0\% (Fig. 5b) and $+20 \%$ (Fig. 5c) for spring (MAM), summer (JJA), autumn (SON), winter (DJF) and the whole year. The catchments for which this number is "significant" (i.e. large or small) are indicated by black (90\% RCM simulations agree) and grey (2/3 RCM simulations agree) colour. Note that values between 4 and 10 imply that at least a third of the RCM simulations give opposite result than the rest and this result is therefore rather uncertain.

Seasonal decreases larger than 20\% (Fig. 5a) are not very likely except the catchments in the south of the Czech Republic in summer. For the same area such a large decrease is neither confirmed nor rejected in spring and autumn. In addition, most RCM simulations agree on a smaller decrease than $20 \%$ in the northern part of the Czech Republic in spring and also in annual water balance. Large decrease in winter runoff is very unlikely, since for the most of the basins $90 \%$ of the RCM simulations confirm the changes larger than $-20 \%$.

Fig. 5b) indicates how RCM simulations agree in sign of the relative changes in runoff, i.e. the figure gives the number of models for which the relative change in runoff is positive. In general, for each season the sign of the changes is the same for most of the basins. Again, there is a good agreement between the RCM simulations in a decrease of the seasonal runoff in southern part of the Czech Re- 
$\mathrm{T}$ a b 1 e 2. Absolute changes of precipitation, runoff and actual evapotranspiration for the 8 river basin districts in the Czech Republic (see Fig. 1. HSL - Upper and middle Elbe, HVL - Upper Vltava, BER - Berounka, DVL - Lower Vltava, ODL - Odra and lower Elbe, ODR - Odra, Mor - Morava, DYJ - Dyje).

\begin{tabular}{|c|c|c|c|c|c|c|c|c|c|}
\hline & & HSL & HVL & BER & DVL & ODL & ODR & MOR & DYJ \\
\hline \multirow[t]{3}{*}{ Winter } & precipitation & 25.71 & 20.67 & 22.86 & 18.87 & 24.81 & 21.21 & 20.71 & 19.33 \\
\hline & runoff & 2.62 & -4.16 & -1.9 & -1.33 & -1.59 & -1.76 & -2.28 & -0.29 \\
\hline & evapotranspiration & 16.16 & 17.23 & 16.36 & 16.18 & 16.6 & 16.68 & 16.72 & 15.76 \\
\hline \multirow[t]{3}{*}{ Spring } & precipitation & 24.81 & 17.52 & 19.13 & 16.07 & 22.45 & 22.41 & 20.47 & 16.95 \\
\hline & runoff & 14.03 & -1.06 & 0.58 & -3.76 & 4.38 & 7.07 & -0.17 & -3.88 \\
\hline & evapotranspiration & 24.28 & 25.4 & 24.66 & 26.29 & 24.75 & 23.31 & 24.96 & 25.97 \\
\hline \multirow[t]{3}{*}{ Summer } & precipitation & -30.37 & -25.11 & -20.9 & -23.59 & -22.57 & -40.07 & -31.7 & -23.32 \\
\hline & runoff & -16.98 & -16.79 & -10.18 & -9.33 & -8.86 & -26.59 & -16.86 & -9.58 \\
\hline & evapotranspiration & 2.53 & 4.35 & -0.8 & -6.25 & 0.1 & 0.76 & -2.2 & -5.61 \\
\hline \multirow[t]{3}{*}{ Autumn } & precipitation & 16.89 & 11.5 & 14.59 & 11.47 & 16.83 & 7.55 & 7.41 & 9.53 \\
\hline & runoff & -23.75 & -19.69 & -11.41 & -12.12 & -13.02 & -26.17 & -17.46 & -12.87 \\
\hline & evapotranspiration & 19.2 & 22.21 & 19.45 & 15.54 & 20 & 18.63 & 15.21 & 13.86 \\
\hline \multirow[t]{3}{*}{ Annual } & precipitation & 37.03 & 24.59 & 35.68 & 22.82 & 41.52 & 11.09 & 16.89 & 22.49 \\
\hline & runoff & -24.08 & -41.69 & -22.92 & -26.54 & -19.09 & -47.46 & -36.77 & -26.63 \\
\hline & evapotranspiration & 62.17 & 69.18 & 59.67 & 51.77 & 61.45 & 59.37 & 54.68 & 49.98 \\
\hline
\end{tabular}

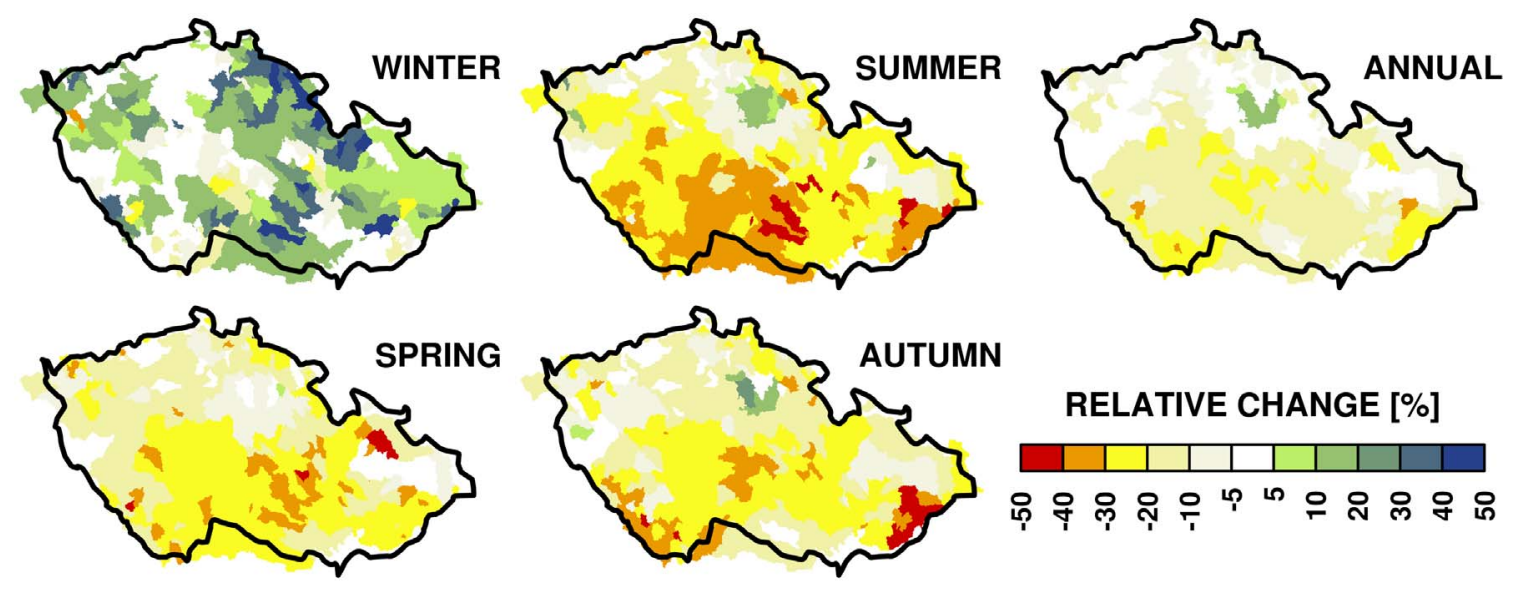

Fig. 4. Seasonal and annual relative changes in runoff [\%] between the control and scenario period. Note that the changes are mostly positive in winter and negative in the other seasons. 
(a) rel. change $>-20 \%$
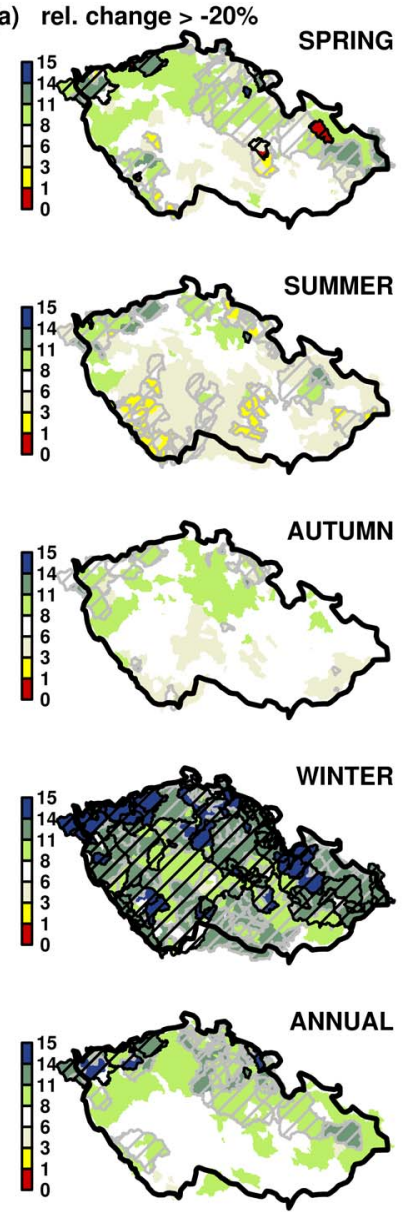

(b) rel. change $>0 \%$
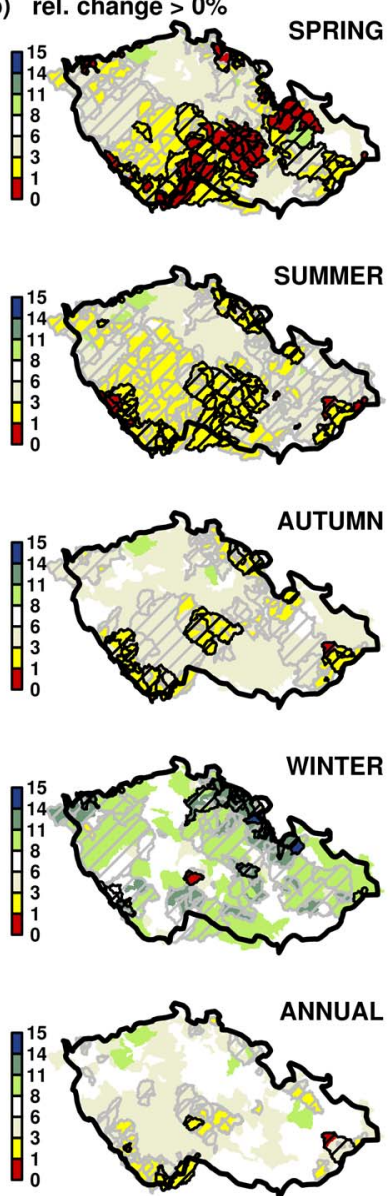

(c) rel. change $>20 \%$

SPRING
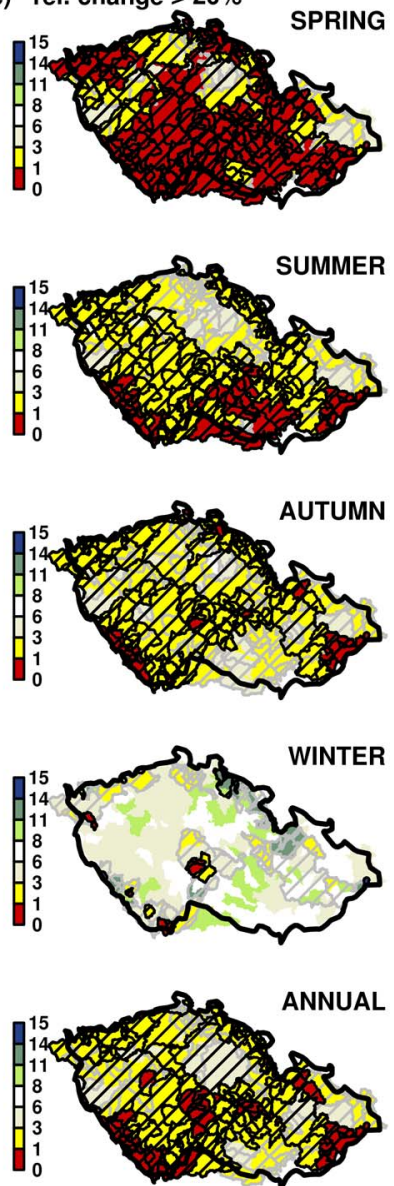

Fig. 5. Uncertainty in the relative changes in runoff expressed as a number of RCM simulations for which the seasonal runoff (a) does not decrease more than $20 \%$, (b) increases, and (c) increases more than $20 \%$. The catchments for which this number is "significant" (i.e. large or small) are indicated by the black $(90 \%$ of the RCM simulations agree) or grey $(2 / 3$ of the RCM simulations agree) colour.

public in spring and summer. Nevertheless, in both seasons there are isolated areas in north-east and north-west showing increase in runoff. These areas are highly elevated and the increases might be related to the orographic effects. The sign of change for autumn runoff is rather uncertain and this also holds for the winter and especially annual water balance. In a number of catchments across the Czech Republic the simulations suggest an (insignificant) increase larger than $20 \%$ (Fig. 5c) in winter. This is not the case in the other seasons for any of the basins.

\section{Conclusions}

We examined the seasonal changes in runoff as projected by a number of regional climate models for the Czech Republic. In general, except for summer, the increase in evapotranspiration due to temperature increase is counterbalanced by the increase in precipitation, hence the changes in runoff from January until May are dominated by the temperature driven changes in dynamics of the snow water storage (shift from spring to winter). Changes in the summer season are mainly related to the decrease in precipitation. The role of changes in evapotranspiration in the summer season is limited by the available water. Overall, the considered regional climate model simulations indicate increase of winter runoff and its decrease in the rest of the year.

Although there is a large uncertainty in the climate modelling and also the absolute values of the relative changes in runoff vary considerably among the models, robust patterns can be identified for the area of the Czech Republic. In general, the spring and summer decrease is more evident in south and south-east part of the Czech Republic and the simulations agree on more than $20 \%$ decrease in runoff in south of the Czech Republic in summer. The 
increase in runoff in winter is rather uncertain only few more than a half of the RCM simulations project increase and in general, the increase in winter runoff is more uncertain than the decrease in summer runoff. In addition, since the increase in winter runoff is to a large extent due to the shift in snow melt, the changes are not consequent to the increase in resources (precipitation) but rather only to changes in seasonal distribution of water.

The uncertainty in the estimated winter runoff propagates into the changes in annual water balance, which has an important consequence for the development of adaptation strategies and measures. For instance, if the increase in winter runoff could compensate for the decrease in runoff in the rest of the year, the possible adaptation measure could be to accumulate the water in winter and release it during the dry period. This emphasizes the need for further research on projected changes in seasonal variability of runoff, for investigation of feasible water transfers between the basins and most importantly for protection of the areas potentially suitable for construction of reservoirs with sufficient volume to enable seasonal/multi-annual water management.

The methodology used in this paper considers only the changes in mean of the monthly precipitation, temperature and air humidity without taking into account the changes in variability. The climate model simulations, however, suggest that this assumption is not always met. The extent to which these changes in variability affect the estimated changes in runoff will be investigated further.

Finally, the total uncertainty related to the modelling of hydrological impacts of climate change comprises not only different parametrisations and descriptions of climate processes and feed-backs but also the unpredictable future socio-economic development, natural processes (volcanic and radiative forcing) and also uncertainty connected to hydrological modelling. The multi-model ensemble approach applied in the present paper thus describes only part of these uncertainties.

Acknowledgements. This paper was prepared from the results of the research project on Refining of current estimates of impacts of climate change in sectors of water management, agriculture and forestry and proposals of adaptation measures (project No. SP/1a6/108/07) sponsored by Ministry of the Environment of the Czech Republic and a grant of the Faculty of Environmental Sciences, Czech University of Life Sciences Prague (No. 201042200057). The regional climate model simu- lations studied in this work were partially funded by the EU FP6 Integrated Project ENSEMBLES (Contract number 505539) whose support is gratefully acknowledged. All calculations and plotting was done in $\mathrm{R}$ (A language and environment for statistical computing).

\section{List of symbols}

$$
\begin{array}{ll}
P & \text { - precipitation, } \\
T & \text { - air temperature, } \\
H & \text { - relative air humidity, } \\
\Delta_{m}^{X}(a, b) & \text { - Delta factor for variable } X \text { and month } m \text { between } \\
& \text { the time periods } a \text { and } b, \\
\bar{X}_{m}^{a} & \text { - average } X \text { for month } m \text { in time period } a, \\
X_{i, m}^{o} & \text { - observation of variable } X \text { in year } i \text { and month } m, \\
X_{i, m}^{*} & \text { - projection of variable } X \text { in year } i \text { and month } m .
\end{array}
$$

\section{REFERENCES}

BATES B. C., KUNDZEWICZ Z. W., WU S., PALUTIKOF J. P., eds., 2008: Climate Change and Water. Technical Paper of the Intergovernmental Panel on Climate Change. IPCC Secretariat, Geneva.

CHRISTENSEN J. H., HEWITSON B., BUSUIOC A., CHEN A., GAO X., HELD I., JONES R., KOLLI R. K., KWON W.-T., LAPRISE R., MAGAÑA RUEDA V., MEARNS L., MENÉNDEZ C. G., RÄISÄNEN J., RINKE A., SARR A., WHETTON P., 2007: Regional Climate Projections. In: Climate Change 2007: The Physical Science Basis. Contribution of Working Group I to the Fourth Assessment Report of the Intergovernmental Panel on Climate Change (SOLOMON S., QIN D., MANNING M., CHEN Z., MARQUIS M., AVERYT K. B., TIGNOR M., MILLER H. L. (eds.). Cambridge University Press, Cambridge, United Kingdom and New York, USA.

FOWLER H. J., KILSBY C. G. \& STUNELL J., 2007: Modelling the impacts of projected future climate change on water resources in north-west England. Hydrol. Earth Syst. Sci., $11,3,1115-1126$.

FOWLER H. J., WILBY R. L., 2010: Detecting changes in seasonal precipitation extremes using regional climate model projections: Implications for managing fluvial flood risk. Water Resour. Res., 46, (W03525).

GRAHAM L. P., ANDRÉASSON J., CARLSSON B., 2007a): Assessing climate change impacts on hydrology from an ensemble of regional climate models, model scales and linking methods - a case study on the Lule River basin. Climatic Change, 81, 293-307.

GRAHAM L. P., HAGEMANN S., JAUN S., BENISTON M., 2007b): On interpreting hydrological change from regional climate models. Climatic Change, 81, 97-122.

HANEL M., 2007: Vliv klimatických změn na hydrologický režim povodí Jizery podle regionálních klimatických scénářù. VTEI, 49, 2, 6-9.

HANEL M., VIZINA A., 2010: Hydrologické modelování dopadů změn klimatu $\mathrm{v}$ denním kroku: korekce systematických chyb a př́růstková metoda. VTEI, 52, 2, 17-21. 
HANEL M., BUISHAND T. A., 2012: Multi-model analysis of RMC simulated 1-day to 30-day seasonal precipitation extremes in the Czech Republic. J. Hydrol., 412-413, 1-2, $141-150$

HEWITT C. D., GRIGGS D. J., 2004: Ensembles-based predictions of climate changes and their impacts. Eos, 85 , $52,566$.

HLADNÝ J., BUCHTELE J., DOUBKOVÁ M., et al., 1997: Impacts of potential climate change on hydrology and water resources in the Czech Republic. Národní klimatický program České republiky, 26, Praha.

HORÁČEK S., KAŠPÁREK L., NOVICKÝ O., 2008: Estimation of climate change impact on water resources by using Bilan water balance model. IOP Conf. Series: Earth and Environmental Science, 4 (012023), 1-7.

KAŠPÁREK L., NOVICKÝ O., PELÁKOVÁ M., 2006: Climate change and water regime in the Czech Republic. T. G. Masaryk Water Research Institute, ISBN 80-85900-63-7.

KAŠPÁREK L., 1998: Regional study on impacts of climate change on hydrological conditions in the Czech Republic. Výzkumný ústav vodohospodářský, Práce a studie, 193, Praha.

KILSBY C. G., TELLIER S. S., FOWLER H. J., HOWELS T. R., 2007: Hydrological impacts of climate change on the Tejo and Guadiana Rivers. Hydrol. Earth Syst. Sci., 11, 3, $1175-1189$.

KYSELÝ J., BERANOVÁ R., 2009: Climate-change effects on extreme precipitation in central Europe: uncertainties of scenarios based on regional climate models. Theor. Appl. Climatol., 95, 3-4, 361-374.

KYSELÝ J., GAÁL L., BERANOVÁ R., 2011: Projected changes in flood-generating precipitation extremes over the Czech Republic in high-resolution regional climate models. J. Hydrol. Hydromech., 59, 4, 217-227.

NĚMEČKOVÁ S., SLÁMOVÁ R., ŠÍPEK V., 2011: Climate change impact assessment on various components of the hydrological regime of the Malše River basin. J. Hydrol. Hydromech., 59, 2, 131-143.

ŠTEPÁNEK P., ZAHRADNÍCEK P., HUTH, R., 2011: Interpolation techniques used for data quality control and calculation of technical series: an example of a Central European daily time series. Idöjárás - Quarterly Journal of the Hungarian Meteorological Service, 115, 1-2, p. 87-98.

TALLAKSEN L. M., VAN LANEN H. A. J., 2004: Hydrological Drought - Processes and Estimation Methods for Streamflow and Groundwater. Elsevier. Amsterdam.

VIZINA A., HORÁČEK S., 2009: Zpřesnění odhadů dopadů klimatické změny na vodní zdroje $\mathrm{s}$ využitím scénářů založených na simulacích modelem ALADIN. VTEI 51, 1, $5-8$.

Received 13 September 2011 Accepted 19 June 2012 